\title{
Effect of Immune Enhancement on Clinical Outcomes of Breast Cancer Patients Receiving Chemotherapy
}

\author{
Naser Abdel Bary ${ }^{1}$, Sohair M. Waheid ${ }^{2}$, Maha ElBassuoni ${ }^{3}$, Amal Shehata ${ }^{2}$, Suzan AlHassanin ${ }^{1}$, \\ Seham M. Emam² and Wesam S. Morad ${ }^{4}$
}

\begin{abstract}
${ }^{1}$ Oncology department- Faculty of medicine- Menofia University. ${ }^{2}$ Nursing department- Faculty of medicine- Menofia and Alexandria University. ${ }^{3}$ Clinical Pathology department- Faculty of medicineMenofia University and ${ }^{4}$ Environmental Health of Liver- National Liver Institute-Menofia University.
\end{abstract}

Background: Breast cancer is the most prevalent cancer among women that require long term treatment and affect many areas of life for patients and their family.

The aim of this study: Was to determine the effect of immune enhancement on clinical outcomes of mastectomy patients undergoing chemotherapy.

Patients and Methods: The study was conducted at oncology department, Menofia University Hospital. A sample of 60 adult female patients with early stage breast cancer who are eligible to adjuvant chemotherapy was selected and randomly assigned alternatively into two equal groups of 30 patients. Study (Group I): was taken health teaching about management of chemotherapy side effects and immune enhancement through (diet, exercise, and lifestyle modification), while control (Group II): was exposed to routine hospital care. Five tools were utilized for data collection.

Results: There was an improvement of a mean total knowledge score among study group at pre intervention $(2.60 \pm 2.19)$ than control group at post intervention $(5.97 \pm 3.09,6.80 \pm 3.41,8.27 \pm 3.41 \mathrm{after} 1 \mathrm{st}, 3 \mathrm{rd}$ and 6 th cycle of chemotherapy respectively).A statistically significant difference found in fatigue $(P$-value: $<0.01)$ and performance status $(P$-value: $<0.05)$ for study group than control group. Regarding quality of life (QOL) measures there was no statistically significant differences existed between both groups pre intervention $(P$-value $>0.05)$, however, a statistically significant difference noticed $(P$-value: $<0.05)$ in physical $(14.33 \pm 1.58)$, social $(10.8 \pm 2.6)$, psychological $(13.6 \pm 2.06)$, functional items $(11.90 \pm 2.18)$ and patient's concerns related to disease $(19.03 \pm 1.96)$ of the study group after interventions after 1stcycle of chemotherapy and highly statistically significant $(P$-value: $<0.01)$ after the $3 \mathrm{rd} \& 6$ th cycles of chemotherapy A positive effect of immune enhancement was also noted on nutritional status (statistically significant differences $(P$-value: $<0.05)$ existed between both groups regarding number $\&$ regularity of meals per day, type of meat, chicken, vegetables, and methods of cooking food).।

Conclusions: management of chemotherapy side effects and immune enhancement through (diet, exercise, and life style modification ) have a positive effect on reduction of chemotherapy side effects, fatigue, and improvement of patient's nutritional status, performance status for usual activities, and (QOL). Results of this study could be applied to assess the clinical benefit (response rate and survival) of such educational protocols on our patients.

Key words: immune enhancement, clinical outcomes, breast cancer, chemotherapy.

Corresponding Author: Dr. Suzan AlHassanin

E-mail: suzanalhassanin@gmail.com

\section{INTRODUCTION}

Cancer is a disruptive and life threatening experience that affects all aspects of life whether physical, psychological, social, and spiritual. It has continued to be major health problem ${ }^{1}$. Breast cancer is a disease that strikes women. It is the most frequently diagnosed cancer and the second leading cause of cancer death after lung cancer in females ${ }^{2}$. The most common chemotherapy agents act by killing cells that divide rapidly and not discriminate between the normal and the malignant cells and as a result, the patient will experience certain side effects following their administration as; nausea, vomiting, diarrhea, skin problems, alopecia, immune suppression, hematological complications, and fatigue ${ }^{3}$. A weakened immune system may be unable to fight off harmful bacteria, germs and infections. There are some interventions that can strengthen theimmune system through stress reduction, diet and physical activity. Nutrition plays a major role in supporting the production 


Vol. 9 | No. 3-4 $2013 \quad$ Naser Abdel Bary et al.

and action of both the cells and the soluble factors of the immune system. Protein, antioxidants, essential fatty acids, and certain vitamins, and minerals are all keys to a healthy immune system. Also moderate exercise helps to quickly circulate white blood cells, part of the immune system's response to foreign bacteria, allowing a quick response to illness ${ }^{4}$. Nursing care of patients receiving chemotherapy begins with physical and psychological preparation. The oncology nurse must review the treatment plan with oncologist to be aware of expected outcomes and possible complications, and assess the patient's general physical and emotional status ${ }^{5}$. The aim of the current study is to determine the effect of immune enhancement on clinical outcomes of mastectomy patients undergoing chemotherapy.

\section{SUBJECTS AND METHOD}

A case control hospital based study was conducted at oncology department, Menofia University Hospital. Data were collected from February to December 2011 over a period of 11 months.A sample of 60 adult female patients with early stage breast cancer were selected and randomly assigned by simple random sample matched cases with control (two equal groups of 30 patients: Study (Group I): received health teaching about management of chemotherapy side effects and immune enhancement through (diet, exercise, and lifestyle modification), while control (Group II): exposed to routine hospital care).

\section{Inclusion criteria:}

- Written consent

- Age from 30-60 years old newly admitted to chemotherapy.

- White blood cells and red blood cells within normal value.

- No other associated diseases as diabetes mellitus.

- Patients received adjuvant chemotherapy in the form of FAC (Fluorouracil-DoxorubicinCyclophosphamide) regimen repeated every 21 days for 6 cycles.

Health teaching done through:

1. First session: Started before chemotherapy administration in the outpatient clinic where the researcher provided patient with basic knowledge about breast cancer, chemotherapy treatment.

2. Second session: It was carried out before chemotherapy administration. The researcher refreshed the previous knowledge and then provided health teaching about management of others chemotherapy side effects.

3. Third session: During chemotherapy administration the researcher refreshed the previous knowledge and then provided health teaching about immune enhancement through: moderate regular exercise and lifestyle modification such as eating fruits and vegetables that are considered rich sources of antioxidants. Moreover a booklet of colored pictures was distributed to each patient.

4. Following sessions: were carried out after the first, 3rd and 6 thcycles of chemotherapy administration to assess any change from baseline data and to ensure the patient follow the instruction that were given. The researcher provided the patient with information according to the patient needs. Blood sample was taken from patients to assess potential carcinogens biomarker CD $90(+v e)$ and CD $45(+v e)$ two times before chemotherapy and after six cycle of chemotherapy by flow cytometery in clinical pathology department, Menofia university hospital.

\section{Five tools were used to collect pertinent data:}

1. Structured interview questionnaire: to assess patient's knowledge about breast cancer, and its treatment side effects.

2. The Australia-modified Karnofsky performance status scale by Abernethy et al.

3. The Quality of life scale by Brady et al.

4. Piper Fatigue Scale by Piper et al.

5. Nutritional assessment sheet.

\section{Statistical analysis:}

Data entry and statistical analysis were done using SPSS version 11 .

- Qualitative categorical variables were compared using chi-square test.

- T-test and Mann-Whitney test were used to determine the level of significance between the quantitative variables for both groups.

- $\quad$ Paired $t$-test was used for comparison of changes in mean values of two situations for the same group.

- $\quad P$-Value of 0.05 or less was used to assess the significance of results (Mann, 2004).

\section{RESULTS}

The mean age in both groups was about 42 and 41 and mostly both were from rural areas. All patients characteristics are seen in Table (1). There was an improvement of a mean total knowledge score among study group $(2.60 \pm 2.19)$ at pre intervention to become $5.97 \pm 3.09$ after 1 st cycle of chemotherapy, $6.80 \pm 3.41$ after 3rd cycle of chemotherapy, and $8.27 \pm 3.41$ after 6 th cycle of chemotherapy) than control group at post intervention. Table (2) shows the effect of teaching on patient's knowledge related to immune system.A statistical significant differences existed in performance status for usual activities between both 
groups after 1st cycle of chemotherapy, after 3rd cycle of chemotherapy and after the 6th cycle of chemotherapy post intervention in relation to performance status for usual activities as $(P$ - value $<0.05)$.Post intervention fatigue in Table (3) showed statistically significant improvement between study and control groups after 3 rd and 6th cycle of chemotherapy $(P$-value: $<0.01)$. As seen in Table (4) there were statistically significant differences existed between study and control groups regarding number of meals taken per day, taking regular meals, type of meat, chicken, vegetables, and methods of cooking food after 3rd and 6th cycles of chemotherapy.
And there was statistically significant differences existed regarding eating fruits $(P$-value: $<0.05)$, and buying food ( $P$-value: $<0.01)$ post intervention (after 3 rd and 6th cycles of chemotherapy).After chemotherapy there was a statistical significant improvement $(P$-value: $<0.05)$ in mean value of hemoglobin $(12.0 \pm 0.5)$, hematocrit (37.04 \pm 1.8$)$, WBCs $(5.0 \pm 0.46)$ and albumin $(4.1 \pm 0.21)$ for study group. There was a statistically significant $(P$-value: $<0.05)$ decrease in the mean value of (CD90 (+ve) CD45 (+ve) \%) $(8.37 \pm 2.45)$ in the study group than $(11.24 \pm 2.99)$ of the control group. The effect on (QOL)is shown in Table (5).

Table 1: Socio-demographic characteristics of both groups.

\begin{tabular}{|c|c|c|}
\hline \multirow{2}{*}{ Items } & Study $(n=30)$ & Control $(n=30)$ \\
\hline & No. $\%$ & No. $\%$ \\
\hline \multicolumn{3}{|l|}{ Age (Year): } \\
\hline $30-<40$ & $9(30)$ & $11(36)$ \\
\hline $40-<50$ & $16(53)$ & $15(50)$ \\
\hline $50-60$ & $5(16)$ & $4(13)$ \\
\hline Mean \pm SD & $42.17 \pm 6.98$ & $41.20 \pm 6.49$ \\
\hline \multicolumn{3}{|l|}{ Marital status: } \\
\hline Single & 1(3) & 0 \\
\hline Married & $27(90)$ & $26(86)$ \\
\hline Widow & $2(6)$ & $4(13)$ \\
\hline \multicolumn{3}{|l|}{ Education: } \\
\hline Illiterate & $9(30)$ & $10(33)$ \\
\hline Read \& write & $7(23)$ & $9(30)$ \\
\hline Secondary school & $8(26)$ & $6(20)$ \\
\hline University grade & $6(20)$ & $5(16)$ \\
\hline \multicolumn{3}{|l|}{ Occupation: } \\
\hline Housewife & $21(70)$ & $23(76)$ \\
\hline Employed & $9(30)$ & $7(23)$ \\
\hline \multicolumn{3}{|l|}{ No. of children: } \\
\hline Non & $2(6)$ & 1(3) \\
\hline One & $3(10)$ & 1(3) \\
\hline Two & $9(30)$ & $8(26)$ \\
\hline Three or more & $16(53)$ & $20(66)$ \\
\hline \multicolumn{3}{|l|}{ Income: } \\
\hline Sufficient & $15(50)$ & $13(43)$ \\
\hline Insufficient & $15(50)$ & $17(56)$ \\
\hline \multicolumn{3}{|l|}{ Resident: } \\
\hline Rural & $19(63)$ & $21(70)$ \\
\hline Urban & $11(36)$ & $9(30)$ \\
\hline
\end{tabular}


Kasr-El-Aini Journal Of Clinical Oncology And Nuclear Medicine

Vol. 9 | No. 3-4 2013

Naser Abdel Bary et al.

Table 2: Patient's knowledge related to immune system in both groups.

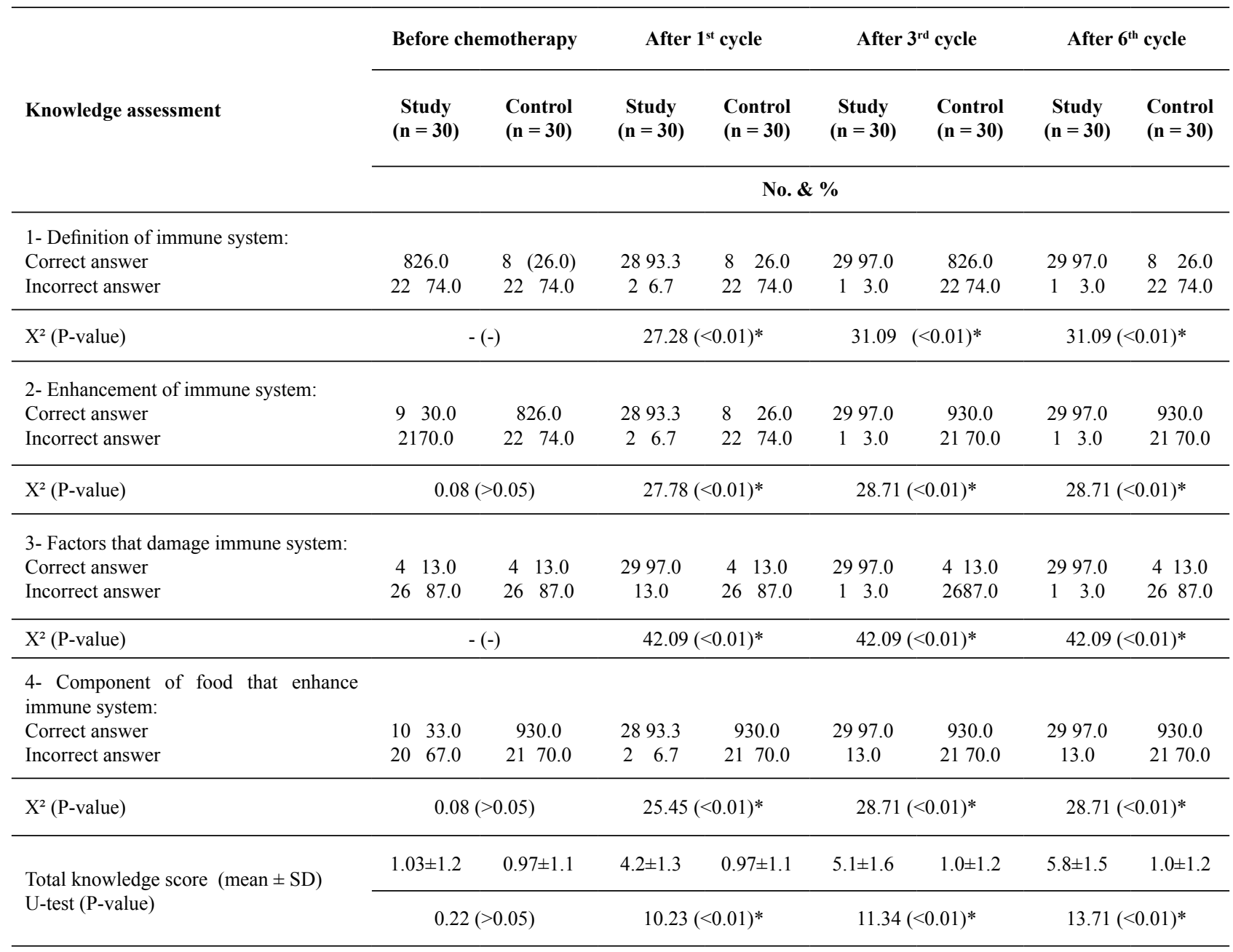

* Statistically significant at $\mathrm{P}<0.05$ (-) test result not valid $\mathrm{U}$-test $=$ Mann Whitney test $\mathrm{X}^{2}=$ chi-square test \# Fisher exact test.

Table 3: Fatigue at different sessions (pre and post intervention).

\begin{tabular}{|c|c|c|c|c|}
\hline Items & $\begin{array}{c}\text { Cases } \\
(\text { No }=30) \\
\text { No. } \& \%\end{array}$ & $\begin{array}{l}\text { Control } \\
(\text { No=30) } \\
\text { No. \&\% }\end{array}$ & $\mathbf{X}^{2}$ & $\begin{array}{c}P \\
\text { Value }\end{array}$ \\
\hline $\begin{array}{l}\text { Before chemotherapy: } \\
\text { Mild } \\
\text { Moderate and severe }\end{array}$ & $\begin{array}{l}17(56.0) \\
13(43.0)\end{array}$ & $\begin{array}{l}16(53.0) \\
14(46.0)\end{array}$ & 0.07 & $>0.05$ \\
\hline $\begin{array}{l}\text { After 1st cycle: } \\
\text { Mild } \\
\text { Moderate and severe }\end{array}$ & $\begin{array}{c}7(23.0) \\
23(77.0)\end{array}$ & $\begin{array}{c}1(3.0) \\
29(97.0)\end{array}$ & $3.61 \#$ & $>0.05$ \\
\hline $\begin{array}{l}\text { After 3rd cycle: } \\
\text { Mild } \\
\text { Moderate and severe }\end{array}$ & $\begin{array}{c}9(30.0) \\
21(70.0)\end{array}$ & $\begin{array}{c}0(0.0) \\
30(100.0)\end{array}$ & 8.37\# & $<0.01 * *$ \\
\hline $\begin{array}{l}\text { After 6th cycle: } \\
\text { Mild } \\
\text { Moderate and severe }\end{array}$ & $\begin{array}{l}11(36.7) \\
19(63.3)\end{array}$ & $\begin{array}{c}2(6.7) \\
28(93.3)\end{array}$ & 7.95 & $<0.01 * *$ \\
\hline
\end{tabular}


Table 4: Nutritional assessment at different sessions.

\begin{tabular}{|c|c|c|c|c|c|c|c|c|}
\hline \multirow{3}{*}{ Nutritional assessment } & \multicolumn{2}{|c|}{ Before chemotherapy } & \multicolumn{2}{|c|}{ After 1st cycle } & \multicolumn{2}{|c|}{ After 3rd cycle } & \multicolumn{2}{|c|}{ After 6th cycle } \\
\hline & $\begin{array}{c}\text { Cases } \\
(n o=30)\end{array}$ & $\begin{array}{c}\text { Control } \\
(n o=30)\end{array}$ & $\begin{array}{l}\text { Cases } \\
(\text { no }=\mathbf{3 0})\end{array}$ & $\begin{array}{c}\text { Control } \\
(\mathrm{no}=\mathbf{3 0})\end{array}$ & $\begin{array}{c}\text { Cases } \\
(n o=30)\end{array}$ & $\begin{array}{c}\text { Control } \\
(\text { no }=30)\end{array}$ & $\begin{array}{c}\text { Cases } \\
(n o=30)\end{array}$ & $\begin{array}{c}\text { Control } \\
(\mathrm{no}=\mathbf{3 0})\end{array}$ \\
\hline & \multicolumn{8}{|c|}{ No.\& \% } \\
\hline $\begin{array}{l}\text { Numbers of meals per day: } \\
2 \\
2+\end{array}$ & $\begin{array}{l}10(34.0) \\
20(66.0)\end{array}$ & $\begin{array}{r}9(30.0) \\
21(70.0)\end{array}$ & $\begin{array}{l}14(46.0) \\
16(54.0)\end{array}$ & $\begin{array}{c}25(83.0) \\
5(17.0)\end{array}$ & $\begin{array}{c}7(24.0) \\
23(76.0)\end{array}$ & $\begin{array}{c}21(70.0) \\
9(30.0)\end{array}$ & $\begin{array}{c}5(17.0) \\
25(83.0)\end{array}$ & $\begin{array}{l}16(54.0) \\
14(46.0)\end{array}$ \\
\hline $\mathrm{X}^{2}$ (P-value) & \multicolumn{2}{|c|}{$0.08(>0.05)$} & \multicolumn{2}{|c|}{$8.86(<0.01)^{* *}$} & \multicolumn{2}{|c|}{$13.13(<0.01)^{* *}$} & \multicolumn{2}{|c|}{$8.86(<0.01)^{* *}$} \\
\hline $\begin{array}{l}\text { Regularity of meals: } \\
\text { Yes } \\
\text { No }\end{array}$ & $\begin{array}{l}15(50.0) \\
15(50.0)\end{array}$ & $\begin{array}{l}17(56.0) \\
13(44.0)\end{array}$ & $\begin{array}{c}14(470) \\
16(53.0)\end{array}$ & $\begin{array}{r}6(20.0) \\
24(80.0)\end{array}$ & $\begin{array}{l}19(64.0) \\
11(36.0)\end{array}$ & $\begin{array}{r}8(27.0) \\
22(73.0)\end{array}$ & $\begin{array}{c}24(80.0) \\
6(20.0)\end{array}$ & $\begin{array}{r}9(30.0) \\
21(70.0)\end{array}$ \\
\hline $\mathrm{X}^{2}$ (P-value) & \multicolumn{2}{|c|}{$0.27(>0.05)$} & \multicolumn{2}{|c|}{$4.80(<0.05)^{*}$} & \multicolumn{2}{|c|}{$8.14(<0.01)^{* *}$} & \multicolumn{2}{|c|}{$15.15(<0.01)^{* *}$} \\
\hline $\begin{array}{l}\text { Type of meat taken: } \\
\text { Free fat } \\
\text { Don't eat fat }\end{array}$ & $\begin{array}{l}10(34.0) \\
20(66.0)\end{array}$ & $\begin{array}{r}8(27.0) \\
22(73.0)\end{array}$ & $\begin{array}{l}19(64.0) \\
11(36.0)\end{array}$ & $\begin{array}{c}5(16.0) \\
25(84.0)\end{array}$ & $\begin{array}{c}22(74.0) \\
8(26.0)\end{array}$ & $\begin{array}{l}8(26.0) \\
22(74.0)\end{array}$ & $\begin{array}{c}24(80.0) \\
6(20.0)\end{array}$ & $\begin{array}{l}10(33.0) \\
20(67.0)\end{array}$ \\
\hline $\mathrm{X}^{2}$ (P-value) & \multicolumn{2}{|c|}{$0.32(>0.05)$} & \multicolumn{2}{|c|}{$13.61(<0.01)^{* *}$} & \multicolumn{2}{|c|}{$13.07(<0.01)^{* *}$} & \multicolumn{2}{|c|}{$13.3(<0.01)^{* *}$} \\
\hline $\begin{array}{l}\text { Type of chicken taken: } \\
\text { Skinless } \\
\text { Don't eat fat }\end{array}$ & $\begin{array}{l}15(50.0) \\
15(50.0)\end{array}$ & $\begin{array}{l}12(40.0) \\
18(60.0)\end{array}$ & $\begin{array}{l}18(60.0) \\
12(40.0)\end{array}$ & $\begin{array}{l}16(53.3) \\
14(46.7)\end{array}$ & $\begin{array}{l}22(74.0) \\
8(26.0)\end{array}$ & $\begin{array}{c}9(30.0) \\
21(70.0)\end{array}$ & $\begin{array}{c}24(80.0) \\
6(20.0)\end{array}$ & $\begin{array}{l}10(33.0) \\
20(67.0)\end{array}$ \\
\hline $\mathrm{X}^{2}$ (P-value) & \multicolumn{2}{|c|}{$0.61(>0.05)$} & \multicolumn{2}{|c|}{$0.27(>0.05)$} & \multicolumn{2}{|c|}{$11.28(<0.01)^{* *}$} & \multicolumn{2}{|c|}{$13.3(<0.01)^{* *}$} \\
\hline $\begin{array}{l}\text { Type of vegetables taken: } \\
\text { Fresh } \\
\text { Cooked and fresh }\end{array}$ & $\begin{array}{c}7(23.0) \\
23(77.0)\end{array}$ & $\begin{array}{c}6(20.0) \\
24(80.0)\end{array}$ & $\begin{array}{c}8(26.0) \\
22(74.0)\end{array}$ & $\begin{array}{c}3(10.0) \\
27(90.0)\end{array}$ & $\begin{array}{l}20(66.0) \\
10(34.0)\end{array}$ & $\begin{array}{c}6(20.0) \\
24(80.0)\end{array}$ & $\begin{array}{c}22(73.0) \\
8(27.0)\end{array}$ & $\begin{array}{c}8(27.0) \\
22(73.0)\end{array}$ \\
\hline $\mathrm{X}^{2}$ (P-value) & \multicolumn{2}{|c|}{$0.1(>0.05)$} & \multicolumn{2}{|c|}{$2.78(>0.05)$} & \multicolumn{2}{|c|}{$11.47(<0.01)^{* *}$} & \multicolumn{2}{|c|}{$11.27(<0.01)^{* *}$} \\
\hline $\begin{array}{l}\text { Fruits taken: } \\
\text { Yes } \\
\text { No }\end{array}$ & $\begin{array}{c}22(74.0) \\
8(26.0)\end{array}$ & $\begin{array}{l}20(67.0) \\
10(33.0)\end{array}$ & $\begin{array}{c}23(77.0) \\
7(23.0)\end{array}$ & $\begin{array}{l}14(47.0) \\
16(53.0)\end{array}$ & $\begin{array}{c}25(840) \\
5(16.0)\end{array}$ & $\begin{array}{c}17(57.0) \\
13(43.0)\end{array}$ & $\begin{array}{c}26(87.0) \\
4(13.0)\end{array}$ & $\begin{array}{l}17(57.0) \\
13(43.0)\end{array}$ \\
\hline $\mathrm{X}^{2}(P$-value $)$ & \multicolumn{2}{|c|}{$0.32(>0.05)$} & \multicolumn{2}{|c|}{$5.71(<0.05)^{*}$} & \multicolumn{2}{|c|}{$5.08(<0.05)^{*}$} & \multicolumn{2}{|c|}{$6.65(<0.05)^{*}$} \\
\hline $\begin{array}{l}\text { Method of cooking: } \\
\text { Boiled } \\
\text { Not boiled }\end{array}$ & $\begin{array}{c}8(27.0) \\
22(73.0)\end{array}$ & $\begin{array}{l}10(33.0) \\
20(67.0)\end{array}$ & $\begin{array}{c}18(60.0) \\
12(40.0)\end{array}$ & $\begin{array}{c}5(16.0) \\
25(84.0)\end{array}$ & $\begin{array}{l}20(67.0) \\
10(33.0)\end{array}$ & $\begin{array}{c}5(17.0) \\
25(830)\end{array}$ & $\begin{array}{c}22(74.0) \\
8(26.0)\end{array}$ & $\begin{array}{c}5(16.0) \\
25(84.0)\end{array}$ \\
\hline $\mathrm{X}^{2}(P$-value $)$ & 0.32 & $0.05)$ & $11.92(<$ & $.01)^{* *}$ & 15.43( & $0.01)^{* *}$ & 19.46 & $0.01)^{* *}$ \\
\hline $\begin{array}{l}\text { Buying food: } \\
\text { Fresh } \\
\text { Canned }\end{array}$ & $\begin{array}{l}14(47.0) \\
16(53.0)\end{array}$ & $\begin{array}{l}12(40.0) \\
18(60.0)\end{array}$ & $\begin{array}{c}18(60.0) \\
12(40.0)\end{array}$ & $\begin{array}{l}12(40.0) \\
18(60.0)\end{array}$ & $\begin{array}{l}20(67.0) \\
10(33.0)\end{array}$ & $\begin{array}{l}11(36.7) \\
19(63.3)\end{array}$ & $\begin{array}{c}24(80.0) \\
6(20.0)\end{array}$ & $\begin{array}{l}13(43.0) \\
17(57.0)\end{array}$ \\
\hline $\mathrm{X}^{2}(P$-value $)$ & 0.27 & $0.05)$ & $2.4(7$ & $.05)$ & 5.41( & $0.05)^{*}$ & 8.53 & $.01)^{* *}$ \\
\hline
\end{tabular}

*Statistically significant at $P<0.05, * *$ Highly Statistical significant at $P<0.01, \mathrm{X}^{2}=$ chi - square test. 


Vol. 9 | No. 3-4 $2013 \quad$ Naser Abdel Bary et al.

Table 5: Quality of life at different sessions.

\begin{tabular}{|c|c|c|c|c|}
\hline Quality of life & $\begin{array}{c}\text { Cases }(\text { no }=30) \\
(\text { Mean } \pm \text { SD) }\end{array}$ & $\begin{array}{l}\text { Control }(\text { no }=30) \\
(\text { Mean } \pm \text { SD) }\end{array}$ & $T$ - Test & $P$ - Value \\
\hline \multicolumn{5}{|l|}{ Before chemotherapy: } \\
\hline Physical & $10.7 \pm 2.4$ & $10.8 \pm 2.3$ & 0.06 & $>0.05$ \\
\hline Social & $12.9 \pm 2.9$ & $12.8 \pm 2.9$ & 0.18 & $>0.05$ \\
\hline Psychological & $11.6 \pm 2.1$ & $11.6 \pm 1.69$ & 0.0 & $>0.05$ \\
\hline Functional & $14.6 \pm 2.83$ & $13.6 \pm 2.9$ & 1.34 & $>0.05$ \\
\hline Patient's concerns related to disease & $16.2 \pm 2.92$ & $16.3 \pm 3.3$ & 0.17 & $>0.05$ \\
\hline \multicolumn{5}{|l|}{ After $1^{\text {st }}$ cycle: } \\
\hline Physical & $14.33 \pm 1.58$ & $15.53 \pm 2.37$ & 2.30 & $<0.05^{*}$ \\
\hline Social & $10.8 \pm 2.6$ & $9.5 \pm 1.69$ & 2.19 & $<0.05^{*}$ \\
\hline Psychological & $13.6 \pm 2.06$ & $14.8 \pm 1.55$ & 2.41 & $<0.05^{*}$ \\
\hline Functional & $11.90 \pm 2.18$ & $10.77 \pm 2.03$ & 2.09 & $<0.05^{*}$ \\
\hline Patient's concerns related to disease & $19.03 \pm 1.96$ & $20.4 \pm 2.96$ & 2.16 & $<0.05^{*}$ \\
\hline \multicolumn{5}{|l|}{ After $3^{\text {rd }}$ cycle: } \\
\hline Physical & $12.9 \pm 1.52$ & $15.0 \pm 1.72$ & 5.01 & $<0.01 * *$ \\
\hline Social & $11.9 \pm 2.7$ & $9.63 \pm 2.06$ & 3.58 & $<0.01^{* *}$ \\
\hline Psychological & $11.9 \pm 1.58$ & $13.3 \pm 1.51$ & 3.50 & $<0.01 * *$ \\
\hline Functional & $13.3 \pm 2.42$ & $11.03 \pm 2.09$ & 3.82 & $<0.01 * *$ \\
\hline Patient's concerns related to disease & $17.93 \pm 1.59$ & $19.2 \pm 2.04$ & 2.68 & $<0.05^{* *}$ \\
\hline \multicolumn{5}{|l|}{ After $6^{\text {th }}$ cycle: } \\
\hline Physical & $11.97 \pm 1.5$ & $14.2 \pm 1.97$ & 4.90 & $<0.01 * *$ \\
\hline Social & $13.3 \pm 2.7$ & $10.1 \pm 2.3$ & 5.06 & $<0.01^{* *}$ \\
\hline Psychological & $11.1 \pm 1.6$ & $12.8 \pm 1.34$ & 4.68 & $<0.01 * *$ \\
\hline Functional & $13.93 \pm 2.5$ & $11.7 \pm 1.99$ & 3.77 & $<0.01 * *$ \\
\hline Patient's concerns related to disease & $17.6 \pm 1.5$ & $18.8 \pm 2.09$ & 2.64 & $<0.05^{*}$ \\
\hline
\end{tabular}

*Statistically significant at $P<0.05, * *$ Highly Statistical significant at $P<0.01$

\section{DISCUSSION}

The problem of dealing with cancer patients becomes more complex especially when those patients are not well educated and do not know enough data about their disease and its management. This problem is significantly high in developing countries. In Menofia governorate we face this problem even in more difficulty as a lot of our patients are illiterate. Up to our knowledge there was no study addressing these issues in breast cancer patients. The knowledge of the present sample at pre intervention revealed that there were no statistically significant differences existed among patients of both groups related to breast cancer, chemotherapy side effects \& its management, and immune system. Coughlane ${ }^{6}$ stated that patients receiving chemotherapy displayed a poor knowledge of the potential side-effects of their chemotherapy and the names of the drugs they were receiving as part of their treatment. The patient's knowledge about chemotherapy side effects and immune system enhancement improved in study group after educations which was supported by Keller $^{7}$ who said that an educational intervention provided by nurses before the start of chemotherapy may assist women with breast cancer to increase their knowledge of chemotherapy treatment, enhance their ability to manage side effects, and improve their coping strategies. An improvement was noticed in the total score of fatigue, performance status, and quality of life among patients in study group over time may be attributed to patient response to intervention that include health teaching about management of chemotherapy side effects, and immune enhancement through (diet, exercise, and life style modification). Nail8 stated that untreated cancer fatigue may result in a decrease or discontinuation of normal physical, social, interpersonal, and recreational activities. Patients may also experience difficulty adhering to and completing treatment regimens and may require delays in treatment, dose limitation, or discontinuation of therapy or may withdraw from clinical trials because of fatigue .Also Brolinson\&Elliott ${ }^{9}$ mentioned that the immune system of people who exercise regularly is stronger than of those who do not. Our study showed that there was statistically significant difference between study and control groups regarding items related to nutritional assessment at different sessions and laboratory results for hemoglobin, hematocrit, albumin, and CD90 (+ve) CD45 (+ve) \%. This might be explained by effective management of chemotherapy side effects such as nausea, and vomiting that has effect on food intake and health teaching about diet, exercise and life style modification that enhance immune system through natural killer (NK) cells and other components of immune system that directly involved in killing cancer cells. This is supported by Wagner and Bornstein ${ }^{10}$ who advised that nutritional assessment should occur at the time of diagnosis, and continue throughout 
the course of treatment. Also Eldridge ${ }^{11}$ stated that side effects of chemotherapy, as well as the cancer itself, can greatly affect nutritional status, healthcare providers need to anticipate possible problems and educate the patient about them in an effort to prevent malnutrition and weight loss which can affect a patient's ability to regain health and acceptable blood counts between chemotherapy cycles. Finally Cadmus, and Salovey ${ }^{12}$, mentioned that the rehabilitation programs for cancer patients involve a combination of physical and psychological interventions that improve the patient's physical comfort and ability to function. We concluded that management of chemotherapy side effects and Immune enhancement has a positive effect on reduction of chemotherapy side effects and fatigue of the study group than control group.So we recommend providing counseling for patients receiving chemotherapy to help them overcome and manage the side effects of chemotherapy. Further research is needed with large sample size for generalization of the results as well as evaluating the clinical benefit (in term of response rate and survival) of breast cancer patients.

\section{REFERENCES}

1. Burke K, LeMone, P, Moehn-Brown, E. Medical-surgical nursing care. 2nd ed. Upper Saddle River, NJ: Prentice Hall; 2007.
2. Breast Cancer Organization. (2012). U.S. Breast Cancer Statistics. Available at: www.breastcancer.org. Retrieved on $4 / 3 / 2012$.

3. Jammy G.Chemotherapy. 2008.

4. Shenker M. How to Increase Immune System with Diet \& Exercise. 2011.

5. Charles H. and Weaver M. Chemotherapy information 2006.

6. Coughlan MC. Knowledge of diagnosis, treatment and its side-effects in patients receiving chemotherapy for cancer. European Journal of Cancer Care.2(2):66-71.

7. Keller JS. Implementation of a prechemotherapy educational intervention for women newly diagnosed with breast cancer. Clinical journal of oncology nursing. 2006;10(1):57-60.

8. Nail LM. Fatigue in patients with cancer. Oncology nursing forum. 2002;29(3):537-46.

9. Brolinson PG, Elliott D. Exercise and the immune system. Clinics in Sports Medicine. 2007;26(3):311-319.

10. Wagner K. and Bornstein J. Nutrition Management during Chemotherapy. Today's Dietitian.11(9):50-9.

11. Eldridge B. Chemotherapy and nutrition implications. (2nd ed.), USA; Lippincott Williams \& Wilkins. 2000, 61-69.

12. Cadmus LA, Salovey P, Yu H, Chung G, Kasl S, Irwin ML. Exercise and quality of life during and after treatment for breast cancer: Results of two randomized controlled trials. Psycho-Oncology. 2009;18(4):343-52. 